\title{
Dr Simon R. F. Price
}

Simon Price has sadly been forced by ill-health to step down from his positions in the Roman Society and to resign his Fellowship at Lady Margaret Hall. He is still hard at work as an independent scholar, finishing some of the writing he had planned and had not yet found time to complete. Since he joined the Editorial Committee of JRS in I989, he has served with scarcely a break on the Committees and the Council of the Society, with periods as Reviews Editor (1989-93), Editor (I996-99), and Chairman of the Editorial Committee (200I-8). It is a fine record of service and all his friends will well remember how he never missed an opportunity to hunt down research work that might be good enough, or could be developed to be good enough, to appear in the Journal. His commitment and enthusiasm will be sadly missed and it is a suitable recognition of them that he has been elected an Honorary VicePresident of the Society.

It is very characteristic of Simon that he has always been a most successful collaborator - in the running of seminars, in the Oxford exchanges with Princeton, in the design and writing of Religions of Rome, in the editing of volumes on the Greek City or the Christian Apologists, above all surely in his collaboration with Lucia Nixon and others on the Sphakia Survey in Eastern Crete, which covers 5,000 years of history and has taken many years of visiting, surveying, writing and publicizing, and is soon to reach its final form as a twovolume publication. Currently, he and I are working together on two collections, as amicably as ever. A talent for collaboration is not the same as being absorbed into a team effort; it is rather a question of knowing how to remain on good working terms while still arguing for your own ideas. Simon's combination of tact and firmness is perfectly attuned to this end and that is why he has achieved and is achieving so much.

I first met Simon when he was starting out as a research student, registered in Oxford, but down to be supervised in UCL. From our first meeting onwards, I remember the very qualities we still associate with him — calmness, focus, responsiveness. He was then as now extremely efficient, entirely without pomposity, wide in his interests and a delightful companion. He came to London with the actual subject of his thesis already firm in his mind, the worship of the Emperor in Asia Minor, which was to finish up as Rituals and Power, a book still inspiring discussion and creativity, so that understanding of that cult has been permanently changed by his work. He himself went on to become a highly successful supervisor in Oxford, remembered by his graduate students as (to quote one of them, James Rives) 'a superb thesis supervisor'; it is a well-earned tribute that they, together with some of his colleagues, are editing a collection of papers in his honour.

I would emphasize other aspects of Simon's achievements. Two things are particularly impressive. First, the range of his published work: not just its chronological extent, but his willingness to write about Greek Religion as well as Roman, about archaeology and surveying techniques as well as history, about dreams and sacrifices as well as historical memory. The other aspect to be emphasized is the way in which Simon's work, whether generated through his own initiative, as part of a group project, or commissioned for a composite work, is always driven by an idea. He is not one of those driven by a desire to cover a certain body of material, or a desire to refute somebody else's ideas, or even a desire to tell a particular story; he is driven by an idea he believes will illuminate an aspect of the past, answer the questions that need answering, shape the material so that the past makes more sense and the people who lived there be given better understanding. It is impossible to overemphasize how important it is to maintain that type of scholarship. One might disagree with whatever he takes as his guiding idea or sometimes think that he has now said enough and should change the subject; but his contribution has always sharpened the issues and always provoked both argument and inventiveness in others. The same is true of many other issues he has touched on. Conceptions and interpretations will move on as they always do and should. But they will continue to be built on Simon Price's foundations.

J. A. N. 